\title{
Varied optical coherence tomography angiography patterns at different stages of macular telangiectasia type 2 - analysis of 15 cases
}

\section{Różnorodny obraz angiografii optycznej koherentnej tomografii u pacjentów z teleangiektazjami okołodołeczkowymi typu 2 - analiza 15 przypadków}

\author{
Joanna Gołęhiewska', Joanna Moneta-Wielgoś2, Monika Turczyńska³, Przemysław Krajewski³, \\ Aleksandra Kuźnik-Borkowska3, Dariusz Kęcik³, Joanna Brydak-Godowska³
}

\author{
Department of General and Experimental Pathology, Medical University of Warsaw, Poland \\ Head: Professor Dariusz Szukiewicz, MD, PhD \\ 2 Department of Ophthalmology, Military Institute of Medicine, Warsaw, Poland \\ Head: Professor Marek Rękas, MD, PhD \\ 3 Department of Ophthalmology Medical University of Warsaw \\ Head: Professor Dariusz Kęcik, MD, PhD
}

Purpose: The aim of the study was to assess vascular patterns in patients with different stages of macular telangiectasia (MacTel) type 2 using optical coherence tomography angiography (OCT-A) and compare these findings with standard fluorescein angiography (FA).

Material and methods: We retrospectively analysed medical records of 15 patients with macular telangiectasia type 2. All patients underwent a comprehensive ocular assessment, including best corrected visual acuity (BVCA), slit-lamp biomicroscopy, dilated fundus examination and colour fundus photography. Fluorescein angiography and optical coherence tomography angiography were performed. The pattern of vascular abnormalities in optical coherence tomography angiography was compared to fluorescein angiography findings.

Results: 15 patients with MacTel 2 were enrolled in the study. The mean age was 62.7 years (range: 46-92). The mean visual acuity was 20/45 (range: 20/20 to 20/150). Hypertension coexists with MacTel 2 in 73.3\% cases. The optical coherence tomography angiography findings included a reduction in density of superficial and deep capillaries, dilated capillaries, and neovascularization in the outer retinal layers. The features seen in optical coherence tomography angiography corresponded well with changes observable in fluorescein angiography. The vascular alterations were asymmetrical in 7 out of 15 patients, which was in keeping with fluorescein angiography findings.

Conclusion: optical coherence tomography angiography is a valuable tool in the assessment of patients with different stages of MacTel 2, even in asymptomatic cases. In this study, the optical coherence tomography angiography showed a high correlation with fluorescein angiography images. More importantly, it revealed subtle vascular changes in 2 eyes, which appeared normal in fluorescein angiography. The optical coherence tomography angiography findings confirm the asymmetrical course of the MacTel 2, which hinders the diagnosis.

Key words: macular telangiectasia, optical coherence tomography, optical coherence tomography angiography, fluorescein angiography.

Abstrakt: Cel: ocena zastosowania angiografii optycznej koherentnej tomografii (OCT-A) w diagnostyce pacjentów z różnymi stadiami teleangiektazji okołodołkowych typu 2. (Mac Tel 2) oraz porównanie uzyskanych obrazów angiografii optycznej koherentnej tomografii z angiografią fluoresceinową.

Materiał i metody: retrospektywnie przeanalizowano dokumentację medyczną 15 pacjentów z teleangiektazjami okołodołkowymi. Każdy pacjent miał wykonane pełne badanie okulistyczne, angiografię fluoresceinową, optyczną koherentną tomografię i angiografię optycznej koherentnej tomografii. Uzyskane w angiografii optycznej koherentnej tomografii skany porównano z wynikami angiografii fluoresceinowej.

Wyniki: średni wiek pacjentów wynosit 62,7 roku (średnio 46-92 lata). W angiografii optycznej koherentnej tomografii we wszystkich 30 oczach pacjentów z Mac Tel 2, niezależnie od stopnia zaawansowania choroby, wykryto rozrzedzenie sieci naczyń w powierzchownym i głębokim splocie naczyniowym siatkówki. Obrazy OCT-A ujawnity także teleangiektatyczne, poszerzone naczynia, szczególnie widoczne w splocie głębokim w 24 oczach, i neowaskularyzację podsiatkówkową w 2 oczach. Zmiany naczyniowe były asymetryczne u 7 spośród 15 pacjentów z Mac Tel 2, podobnie w angiografii fluoresceinowej. Nadciśnienie tętnicze wspótistniało u 73,3\% pacjentów z Mac Tel 2. 
Wnioski: badanie angiografii optycznej koherentnej tomografii wykazało wysoką korelację z obrazami angiografii fluoresceinowej u pacjentów z teleangiektazjami okołodołkowymi oraz dodatkowo ujawniło subtelne zmiany naczyniowe w 2 oczach, w których obraz angiografii fluoresceinowej był prawidłowy. Badania angiografii optycznej koherentnej tomografii potwierdzają asymetryczny przebieg Mac Tel 2, który utrudnia i może opóźniać prawidłowe rozpoznanie. Teleangiektazjom często towarzyszyło nadciśnienie tętnicze, można je rozpatrywać jako jeden z czynników predysponujących do wystąpienia Mac Tel 2.

Slowa kluczowe: teleangiektazje okołodołeczkowe, optyczna koherentna tomografia, angiografia optycznej koherentnej tomografii, angiografia fluoresceionowa.

The authors declare no conflict of interest/ Autorzy zgłaszają brak konfliktu interesów w związku z publikowaną pracą

\section{Introduction}

Gass and Oyakawa were the first to describe macular telangiectasia involving capillary ectasia and dilation in the juxtafoveal region in 1982. They named this condition idiopathic juxtafoveolar retinal telangiectasis (IJRT) and classified it into four groups (1). In 1993, Gass and Blodi modified the first IJRT classification by dividing the eyes into three groups and each group was further subdivided into two other sub-groups (2). In an attempt to simplify the Gass-Blodi classification, Yannuzzi et al. divided IJRT into two broad groups: unilateral aneurysmal telangiectasia or idiopathic macular telangiectasia type 1 (MacTel 1), which occurs predominantly in males, and perifoveal telangiectasia, also known as idiopathic (MacTel 2), that occurs both in men and women, with characteristic features on multimodal imaging (3). Furthermore, Mezad-Koursh et al. described the possible association of Mac Tel 2 with retino-choroidal anastomosis and choroidal neovascularization (4). Clinical presentation of Mac Tel comprises decreased visual acuity, sometimes accompanied by metamorphopsia, and a central scotoma, as the disease slowly progresses. Indirect ophthalmoscopy and stereoscopic dilated fundus photography may be helpful but lack accuracy in detecting telangiectasia, as the earliest ophthalmoscopic changes seen in MacTel are rather subtle and may be easily missed. Over the years, fluorescein angiography (FA) has been the gold standard in diagnosis and classification of telangiectasia $(5,6)$. Optical coherence tomography (OCT) plays a key role in deepening our understanding of Mac Tel by demonstrating structural changes as they occur $(7,8)$. Fundus autofluorescence (FAF) and confocal blue reflectance (CBR) which are also used in the diagnosis of MacTel add to the understanding of morphologic alterations in the disease $(9,10)$.

Optical coherence tomography angiography (OCT-A) is a new, non-invasive tool, based on split-spectrum amplitude-decorrelation angiography (SSADA), involving the detection and measurement of intravascular erythrocyte movement. OCT-A provides three-dimensional maps of macular perfusion and seems to be a promising method in the detection of early microcirculatory disorder (11). To date, there have been several studies focused on OCT-A findings in patients with Mac Tel $2(10-13)$. The aim of our study was to assess vascular patterns at different stages of Mac Tel 2 using OCT-A and determine the relationship between them and FA images.

\section{Materials and methods}

We retrospectively analysed medical records of 15 patients with macular telangiectasia type 2. The diagnosis of Mac Tel was based on FA and OCT characteristics. Every patient underwent a comprehensive ocular assessment, including best-cor- rected visual acuity (BVCA), slit-lamp biomicroscopy, dilatated fundus examination and colour fundus photography. FA was performed using VISUPAC 5.0 Spectralis HRA+OCT, Heidelberg Engineering; Heidelberg, Germany. The exclusion criteria were concomitant retinal pathologies such as diabetic retinopathy, hereditary retinal dystrophies, pathologic myopia (defined as a spherical equivalent of -6 diopters or more), previous laser photocoagulation, and history of uveitis. OCT-A was performed using a commercially available RTVue XR Avanti with AngioVue (Optovue, Fremont, CA, USA), which captures a $3 \times 3$ and $6 \times 6-\mathrm{mm}$ area centered on the fovea. Each OCTA en face image contains $304 \times 304$ pixels created from the intersection of the 304 vertical and the 304 horizontal B-scans. AngioVue automatically segments the area into four layers, including superficial capillary plexus layer (SP), deep capillary plexus layer (DP), outer retina layer and choriocapillaris. The SP en face image was segmented with an inner boundary at $3 \mu \mathrm{m}$ beneath the internal limiting membrane and an outer boundary set at $15 \mu \mathrm{m}$ beneath the inner plexiform layer, whereas the deep capillary plexus en face image was segmented with an inner boundary $15 \mu \mathrm{m}$ beneath the inner plexiform layer and an outer boundary at $70 \mu \mathrm{m}$ beneath the inner plexiform layer. Three scans were acquired for each eye, then the highest quality one (i.e. with a signal strength index $>60$ ) was selected for analysis. OCT B-scans were also acquired in a usual manner to provide retinal cross-sectional images. The OCT-A images were compared with the standard FA imaging and graded as described in Table I and Table II. The grading was decided by two independent retinal experts and the mutually agreed version of the grading was included in the analysis.

\begin{tabular}{|c|c|}
\hline Grade/ Stopień & Characteristics/ Charakterystyka \\
\hline $\mathbf{0}$ & $\begin{array}{l}\text { No visible vascular abnormalities/Bez widocznych } \\
\text { zmian naczyniowych }\end{array}$ \\
\hline 1 & Temporal changes/ Zmiany naczyniowe od skroni \\
\hline 2 & $\begin{array}{l}\text { Temporal and nasal changes/ Zmiany naczyniowe } \\
\text { od skroni i nosa }\end{array}$ \\
\hline 3 & $\begin{array}{l}\text { Full involvement (circumferential vascular } \\
\text { anomalies)/ Zmiany naczyniowe we wszystkich } \\
\text { kwadrantach plamki }\end{array}$ \\
\hline 4 & $\begin{array}{l}\text { Grade 1-3 with signs of subretinal NV/ Neowasku- } \\
\text { laryzacja podsiatkówkowa z cechami stadium 1-3 }\end{array}$ \\
\hline
\end{tabular}

Tab. I. Grading of macular telangiectasia type 2 patients based on FA. Tab. I. Klasyfikacja teleangiektazji okołodołkowych typu 2 na podstawie FA. 


\begin{tabular}{|c|l|}
\hline Grade/ Stopień & \multicolumn{1}{|c|}{ Characteristics/ Charakterystyka } \\
\hline $\mathbf{0}$ & $\begin{array}{l}\text { Only rarefaction of capillaries in superficial/deep } \\
\text { plexus/ Rozrzedzenie naczyn w splocie naczynio- } \\
\text { wym powierzchownym/głębokim }\end{array}$ \\
\hline $\mathbf{1}$ & $\begin{array}{l}\text { Vascular anomalies in the deep and/or superficial } \\
\text { plexus temporal to the fovea/ Zmiany naczyniowe } \\
\text { W w splocie naczyniowym powierzchownym/glę- } \\
\text { bokim skroniowo od doteczka }\end{array}$ \\
\hline $\mathbf{2}$ & $\begin{array}{l}\text { Vascular anomalies in the deep and/or super- } \\
\text { ficial plexus temporal and nasal to the fovea/ } \\
\text { Zmiany naczyniowe w w splocie naczyniowym } \\
\text { powierzchownym/głębokim skroniowo i nosowo } \\
\text { od dołeczka }\end{array}$ \\
\hline 3 & $\begin{array}{l}\text { Full involvement (circumferential vascular } \\
\text { anomalies)/ Zmiany naczyniowe we wszystkich } \\
\text { kwadrantach plamki }\end{array}$ \\
\hline $\mathbf{4}$ & $\begin{array}{l}\text { Neovascularization in the outer retina with any } \\
\text { OCT-A signs of grade 1 to 3/ Neowaskularyzacja } \\
\text { podsiatkówkowa z cechami stadium 1-3 }\end{array}$ \\
\hline
\end{tabular}

Tab. II. Grading of macular telangiectasia type 2 patients based on OCT-A.

Tab. II. Klasyfikacja teleangiektazji okołodołkowych typu 2 na podstawie OCT-A.

This study was approved by the Institutional Bioethics Committee and followed the tenets of the Declaration of Helsinki.

\section{Statistical analysis}

As our empirical data was highly skewed, as well as due to apparent and visibly high concordance between the two investigated diagnostic modalities, we were not inclined to perform a statistical analysis of these phenomena, namely, to obtain the kappa-statistic measure of interrater agreement. In our opinion the significance testing was not feasible; any computation could lead to erroneous or invalid conclusions.

\section{Results}

Fifteen patients (30 eyes) with Mac Tel 2 at different stages of disease were enrolled in the retrospective study. The mean patient age was 62.7 years (range of 46-92). The mean visual acuity was $20 / 45$ with a range of $20 / 20$ to $20 / 150$, with seven eyes having a visual acuity of $20 / 40$ or better. Concomitant hypertension was present in $73.3 \%$ cases. Patient characteristics are summarized in Table III.

The comparison of OCT-A- and FA-based grading is shown in Table IV.

In OCT-A, a rarefaction of superficial and deep capillaries was detected in all 30 eyes of Mac Tel 2 patients, regardless of the stage of the disease. This finding was also confirmed in two eyes with normal FA and OCT images (grade 0). Except for these 2 cases, all OCT-A images corresponded well with the FA observable changes. OCT-A images also revealed teleangiectatic vessels, particularly evident in the deep plexus, coarse irregularities of blood vessels, and subretinal neovascularization in one case. The alterations were most pronounced on the temporal side. In OCT-A, grade 1 was detected in 21 eyes (70\%), grade 2 in 3 eyes (10\%), grade 3 in 2 eyes (6.66\%), grade 4 in 1 eye (3.33\%). The vascular alterations were asymmetrical in 7 out
Mac Tel 2/ Mac Tel 2.

\begin{tabular}{|l|c|}
\hline Patients/ Pacjenci & $15(65.22 \%)$ \\
\hline Age/ Wiek & $63.7 \pm 11.87$ \\
\hline Age (min-max)/ Wiek (min-max) & $47-92$ \\
\hline M/F/ K/M & $5 / 10$ \\
\hline Affected eye/ Zajęte oko & 30 \\
\hline BCVA (log MAR) & $0.196 \pm 0.202$ \\
\hline Snellen Equivalent/ Ekwiwalent sferyczny & $20 / 31$ \\
\hline General Status/ Stan ogólny & \\
\hline Hypertension/ Nadciśnienie tętnicze & $11(73.3 \%)$ \\
\hline Diabetes/ Cukrzyca & 0 \\
\hline $\begin{array}{l}\text { Ischemic heart disease/ } \\
\text { Choroba niedokrwienna serca }\end{array}$ & 2 \\
\hline $\begin{array}{l}\text { Sarcoidosis/asthma/ } \\
\text { Sarkoidoza/astma oskrzelowa }\end{array}$ & 1 \\
\hline
\end{tabular}

Tab. III. Characteristics of the patients $(\mathrm{n}=15)$.

Tab. III. Charakterystyka pacjentów $(n=15)$.

\begin{tabular}{|c|c|c|c|c|c|c|}
\hline $\begin{array}{l}\mathrm{No} / \\
\mathrm{Nr}\end{array}$ & $\begin{array}{l}\text { Sex/ } \\
\text { Pleć }\end{array}$ & $\begin{array}{l}\text { Age/ } \\
\text { Wiek }\end{array}$ & $\begin{array}{c}\text { FA } \\
\text { RE/ OP }\end{array}$ & $\begin{array}{c}\text { FA } \\
\text { LE/ OL }\end{array}$ & $\begin{array}{l}\text { OCT-A } \\
\text { RE/ OP }\end{array}$ & $\begin{array}{l}\text { OCT-A } \\
\text { LE/ OL }\end{array}$ \\
\hline 1 & $\mathrm{~F} / \mathrm{K}$ & 64 & 1 & 0 & 1 & 0 \\
\hline 2 & $\mathrm{~F} / \mathrm{K}$ & 92 & 1 & 3 & 1 & 3 \\
\hline 3 & $\mathrm{~F} / \mathrm{K}$ & 64 & 1 & 1 & 1 & 1 \\
\hline 4 & $M$ & 64 & 2 & 1 & 2 & 1 \\
\hline 5 & $M$ & 47 & 1 & 0 & 1 & 0 \\
\hline 6 & $M$ & 62 & 4 & 1 & 4 & 1 \\
\hline 7 & $\mathrm{~F} / \mathrm{K}$ & 64 & 1 & 3 & 1 & 3 \\
\hline 8 & $\mathrm{~F} / \mathrm{K}$ & 74 & 1 & 1 & 1 & 1 \\
\hline 9 & $\mathrm{~F} / \mathrm{K}$ & 71 & 1 & 1 & 1 & 1 \\
\hline 10 & $\mathrm{~F} / \mathrm{K}$ & 54 & 2 & 2 & 2 & 2 \\
\hline 11 & $\mathrm{~F} / \mathrm{K}$ & 63 & 1 & 1 & 1 & 1 \\
\hline 12 & $M$ & 47 & 4 & 1 & 4 & 1 \\
\hline 13 & $\mathrm{~F} / \mathrm{K}$ & 52 & 1 & 1 & 1 & 1 \\
\hline 14 & $M$ & 64 & 1 & 1 & 1 & 1 \\
\hline 15 & $\mathrm{~F} / \mathrm{K}$ & 60 & 1 & 1 & 1 & 1 \\
\hline
\end{tabular}

$\mathrm{M}$ - man/ męizzyzna, F- female/ K - kobieta, RE - right eye/ OP - oko prawe, LE - left eye/ OL - oko lewe

Tab. IV. Comparison of FA and OCT-A grading of the Mac Tel 2 patients.

Tab. IV. Porównanie wyników klasyfikacji MacTel2 w oparciu o FA i OCT-A.

of 15 patients with Mac Tel 2, in keeping with FA findings. OCT-A revealed dilated, irregular vessels in parafoveal area of all studied eyes. The disease was unilateral in all subjects.

Figures 1.-4. show examples of patients with Mac Tel 2. 


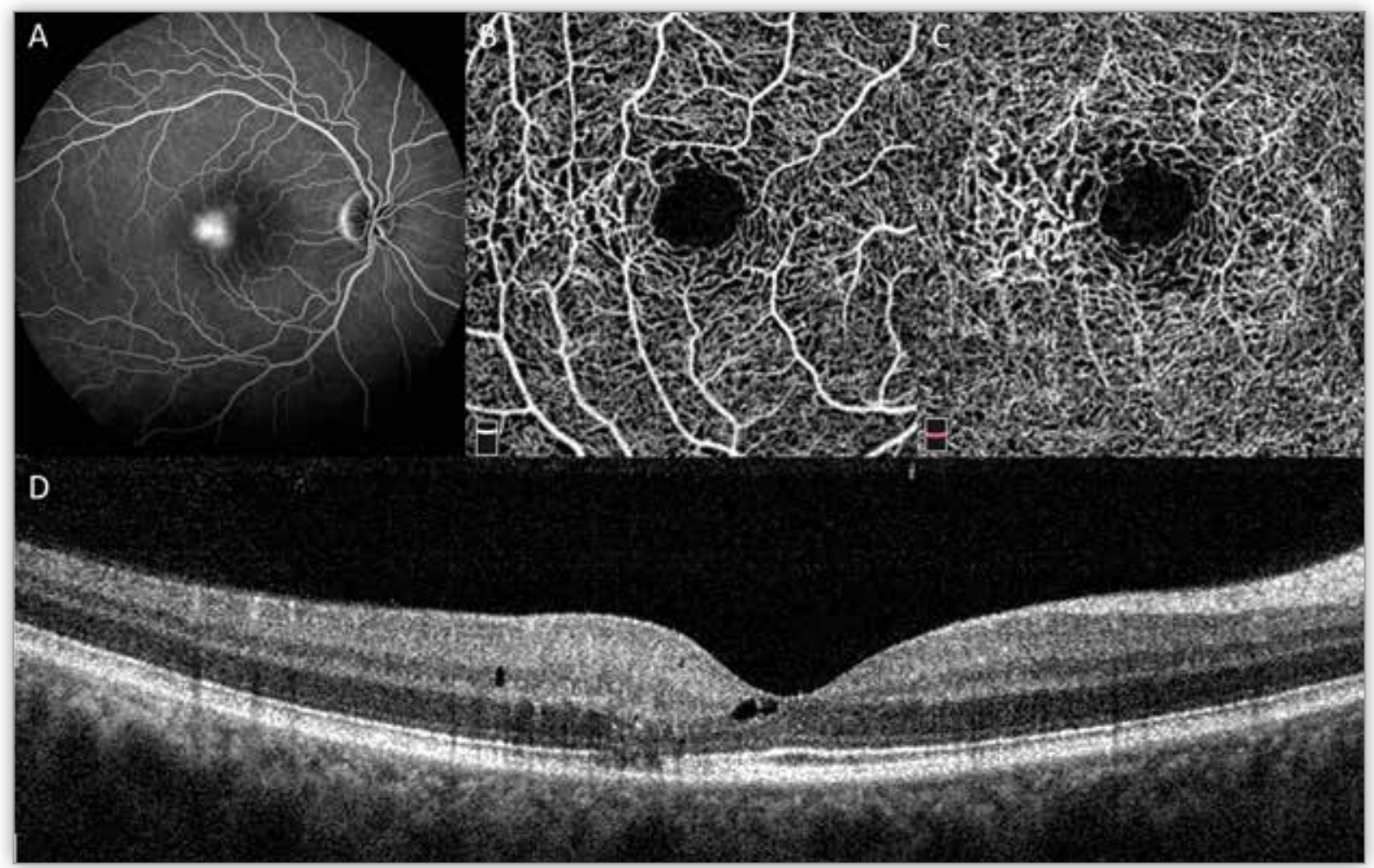

Fig. 1. Patient with Mac Tel 2, right eye (stage 1). A - FA image (late phase) increasing hyperfluorescence with diffusion of the dye at the temporal side of the fovea due to perifoveal telangiectasia. B, C - OCT-A: dilated, irregular vessels temporally to the fovea, more pronounced in deep vascular network. C. D - OCT-B scan: small intraretinal cavities and photoreceptors layer disruption temporally to the fovea.

Ryc. 1. Pacjent z Mac Tel 2, oko prawe (stopień 1). A - obraz FA (faza późna) hiperfluorescencja po stronie skroniowej dołka spowodowana przeciekiem z nieprawidłowych naczyń. B, C - OCT-A: poszerzone naczynia krwionośne o nieregularnym obrysie skroniowo od dołka, bardziej widoczne w splocie naczyniowym głębokim. C, D - OCT-B: niewielkie przestrzenie śródsiatkówkowe i zaburzenia warstwy fotoreceptorów skroniowo od dołka.

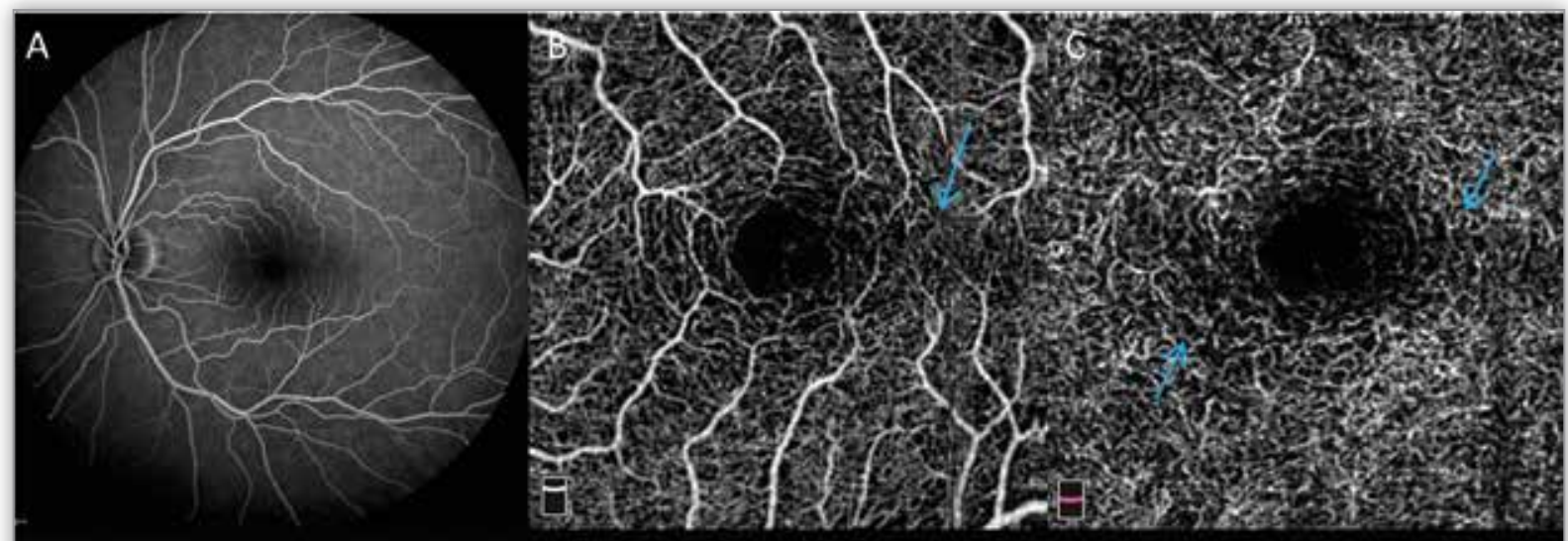

D

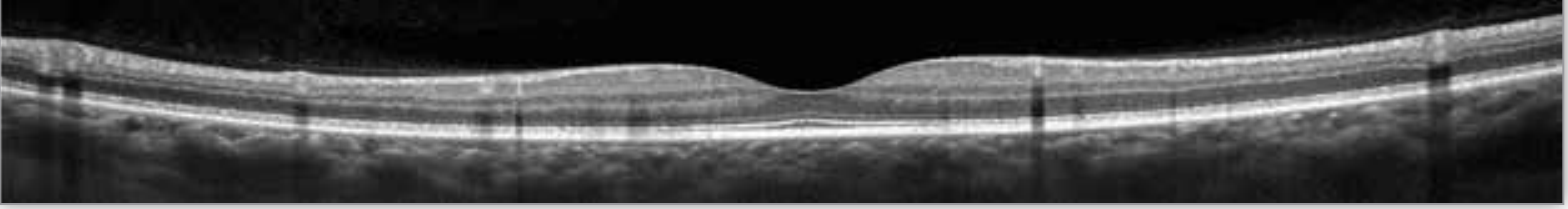

Fig. 2. The same patient, left eye (stage 0 ) A - normal FA image. B - rarefaction of capillaries in superficial capillary plexus temporally and nasally (minimal) to the fovea. C - rarefaction of capillaries in deep capillary network temporally and nasally to the fovea. D - OCT- B scan within normal limits.

Ryc. 2. Ten sam pacjent, oko lewe (stopień 0). A - prawidłowy obraz w FA. B - rozrzedzenie naczyń w splocie naczyniowym powierzchownym skroniowo i nosowo (w minimalnym zakresie) od dołka. C - rozrzedzenie naczyń w splocie naczyniowym głębokim skroniowo i nosowo od dołka. D - prawidłowy obraz w OCT-B. 


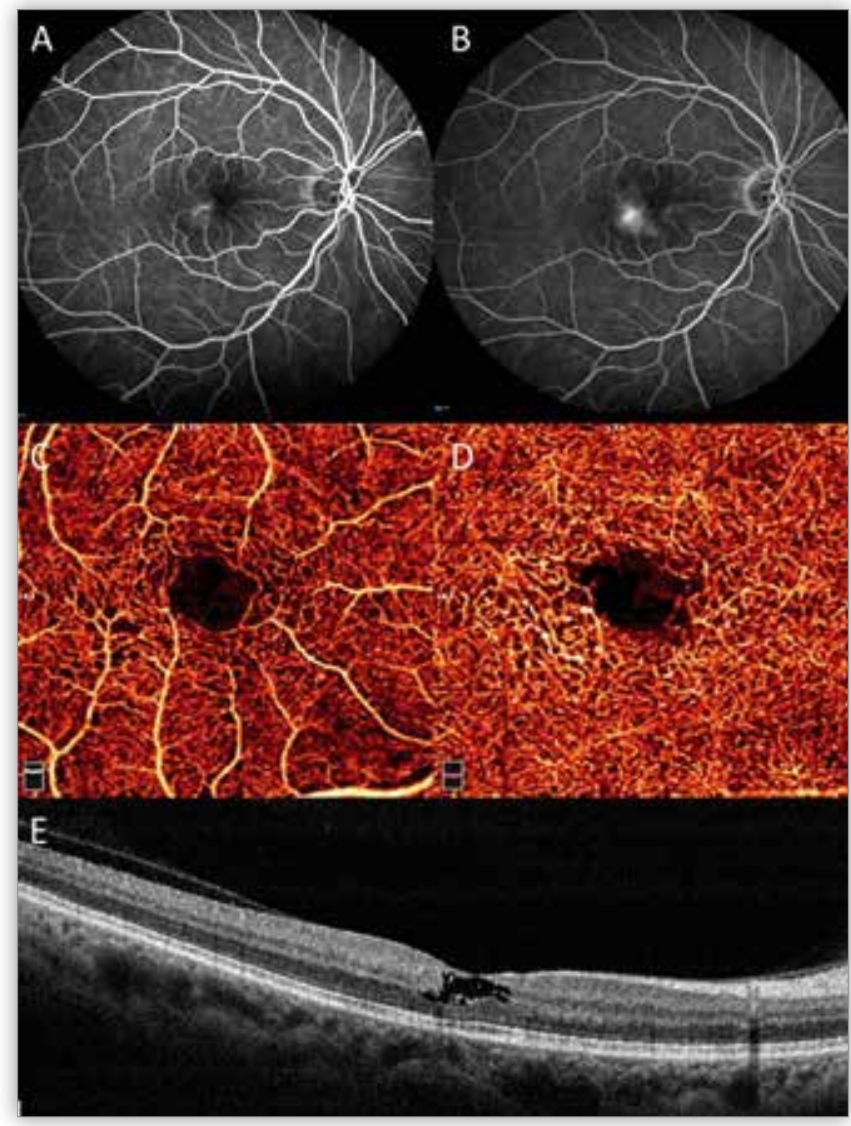

Fig. 3. Mac Tel 2 patient, right eye (stage 1) A, B - FA image (early phase $A$, late phase $B$ ) increasing hyperfluorescence with diffusion of the dye at the temporal side of the fovea due to perifoveal telangiectasia $\mathrm{C}-\mathrm{OCT}-\mathrm{A}$ : increase in space between vessels in superficial capillary plexus. temporally to the fovea. $D$ - OCT-A: dilated, ectatic vessels temporally to the fovea in deep vascular network C. E - OCT- B scan: small intraretinal cavities in the centre of the fovea.

Ryc. 3. Pacjent z Mac Tel 2, oko prawe (stopień 1). A, B- obraz FA (faza wczesna A, faza późna B) - narastająca hiperfluorescencja z dyfuzją barwnika skroniowo od dołeczka, spowodowana przeciekiem z nieprawidłowych naczyń. C- OCT-A rozrzedzenie naczyń w splocie naczyniowym powierzchownym, skroniowo od dołeczka. D- OCT-A - poszerzone, rozdęte naczynia skroniowo od dołeczka w glębokim splocie naczyniowym OCT-B: małe przestrzenie śródsiatkówkowe w centrum dołeczka.

\section{Discussion}

Macular telangiectasia is a rare disease, with the prevalence rate of $0.004-0.1 \%(14,15)$. MacTel may be the cause of serious vision impairment and interventions aimed at inhibiting its progression constitute an important area of research. Advances in optical imaging have revealed multiple retinal structural abnormalities in Mac Tel and added a lot to our understanding of the natural course of the disease. Fluorescein angiography, used since the 1960's, remains the main tool in the assessment of retinal vasculature, however, recent advances in SD-OCT technology have expanded our knowledge of MacTel pathophysiology. OCT images provided evidence that MacTel 2 is a primary neurodegenerative macular disease with secondary vascular involvement. The structural abnormalities in the retinal layers, such as intraretinal hyporeflective spaces, foveal thinning, intraretinal pigment deposits, and foveal detachment, typical of MacTel 2, are evident on OCT, however, OCT B-scan

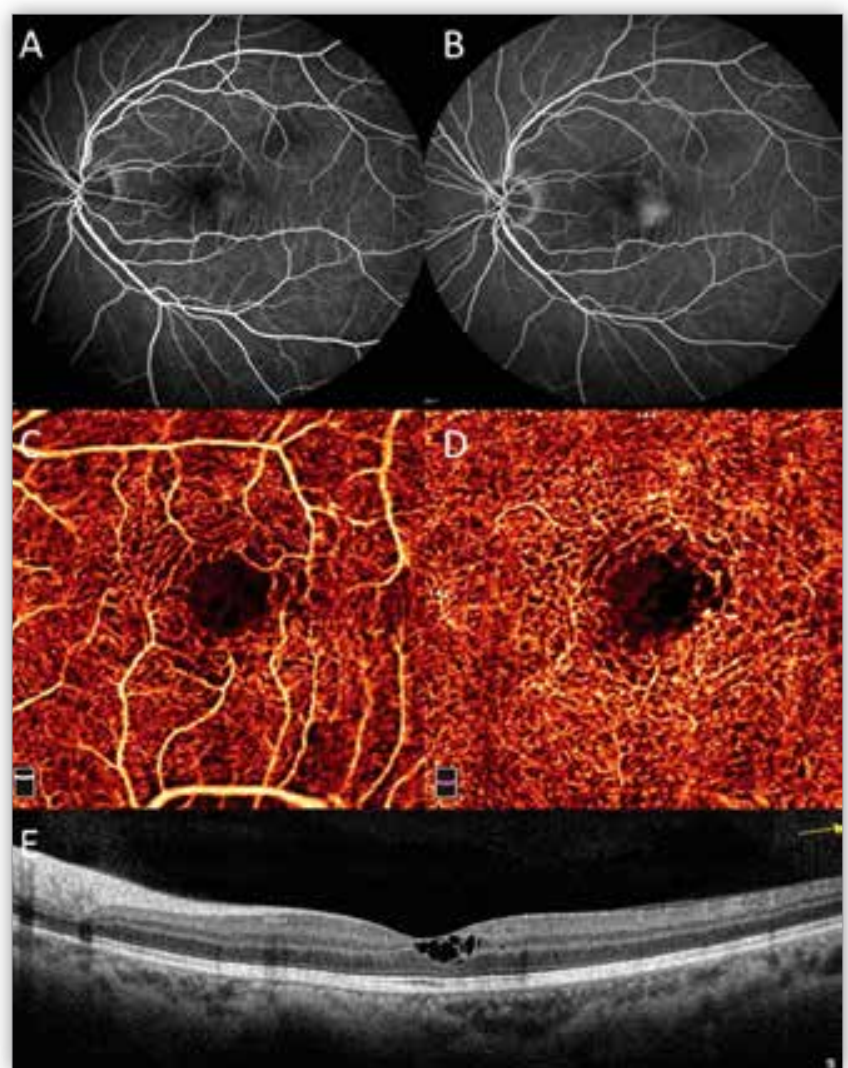

Fig. 4. Mac Tel 2 patient, left eye (stage 1). A, B - FA image (early phase $A$, late phase $B$ ) increasing hyperfluorescence with diffusion of the dye at the temporal side of the fovea due to perifoveal telangiectasia $\mathrm{C}$ - OCT-A: increase in space between vessels in superficial capillary plexus. temporally to the fovea. D - OCT-A: dilated, ectatic vessels temporally to the fovea in deep vascular network - C. E - OCT- B scan: small intraretinal cavities in the centre of the fovea.

Ryc. 4. Pacjent $z$ Mac Tel 2, oko lewe (stopień 1). A, B- obraz FA (faza wczesna A, faza późna B) - narastająca hiperfluorescencja z dyfuzją barwnika skroniowo od dołeczka, spowodowana przeciekiem z nieprawidłowych naczyń. C- OCT-A rozrzedzenie naczyń w splocie naczyniowym powierzchownym, skroniowo od dołeczka. D- OCT-A - poszerzone, rozdęte naczynia skroniowo od dołeczka $w$ głębokim splocie naczyniowym OCT-B: małe przestrzenie śródsiatkówkowe w centrum dołeczka.

images themselves do not facilitate the assessment of retinal microvasculature $(10,11)$. OCT-A-based studies, with its ability to visualize and analyze both superficial and deep retinal vascular plexuses, have provided new insights into the course of the disease, even at very early stages. Our study confirms that OCT-A provides detailed images of retinal microcirculation in patients with MacTel 2. However, we wish to elucidate that MacTel 2, which is a bilateral disease, may manifest with a significant asymmetry of retinal changes, which makes accurate diagnosis much more difficult. In the group of 15 MacTel 2 patients, we found the asymmetrical course of the disease in 7 cases. Two patients with stage 1 of MacTel in one eye had normal FA and OCT findings in the fellow eye. There was no foveal pit asymmetry in these asymptomatic cases, as described by Nalci et al. (12). OCT-A revealed a rarefaction of capillaries in these cases, confirming that it is a powerful method in early detection of microvascular abnormalities. Furthermore, OCT-A provided valuable information so as to disease severity in other 
patients with MacTel 2 with its findings in keeping with other OCT-A studies (13-15). The study demonstrated strong correlations between OCT-A and early and late FA and confirmed the results reported by Toto et al. (10). Despite extensive effort put into the attempts to unpick the pathogenesis of MacTel, there is still a great deal to learn about the disease.

\section{Conclusions}

OCT-A is a valuable tool in the assessment of patients with different stages of Mac Tel 2, even in asymptomatic cases. In this study OCT-A showed a high correlation with FA images. Furthermore, it revealed subtle vascular changes in 2 eyes with normal FA findings. The OCT-A findings confirms the asymmetrical course of the Mac Tel 2, which hinders the diagnosis.

\section{References:}

1. Gass D, Oyakawa RT: Idiopathic juxtafoveolar retinal telangiectasis. Archives of Ophthalmology. 1982; vol. 100, no. 5: 769-780 .

2. Gass D, Blodi BA: Idiopathic juxtafoveolar retinal telangiectasis. Update of classification and follow-up study. Ophthalmology. 1993; vol. 100, no. 10: 1536-1546.

3. Yannuzzi LA, Bardal AMC, Freund KB, Chen KJ, Eandi CM, Blodi B: Idiopathic macular telangiectasia. Archives of Ophthalmology. 2006; vol. 124, no. 4: 450-460.

4. Mezad-Koursh D, Zayit-Soudry S, Barak A, Loewenstein A: Unilateral idiopathic macular telangiectasia with choroidal neovascularization. Ophthalmic Surgery, Lasers, and Imaging. 2010: 1-3.

5. Wu L, Evans T, Arevalo JF: Idiopathic macular telangiectasia type 2 (idiopathic juxtafoveolar retinal telangiectasis type $2 A$, Mac Tel 2). Surv Ophthalmol. 2013; 58: 536-559.

6. Abujamra S, Bonanomi MT, Cresta FB, Machado CG, Pimentel SL, Caramelli CB: Idiopathic juxtafoveolar retinal telangiectasis: clinical pattern in 19 cases. Ophthalmologica. 2000; vol. 214 , no. 6, pp. 406-411.
7. Cohen SM, Cohen ML, El-Jaballi F, Pautler SE: Optical coherence tomography findings in nonproliferative group $2 \mathrm{~A}$ idiopathic juxtafoveal retinal teleangiectasis. Retina. 2007; 27: 59-66.

8. Sallo FB, Leung I, Clemons TE, Peto T, Bird AC, Pauleikhoff D: Multimodal imaging in type 2 idiopathic macular telangiectasia. Retina. 2015; 35: 742-749.

9. Bottoni F, Eandi CM, Pedenovi S, Staurenghi G: Integrated clinical evaluation of type $2 A$ idiopathic juxtafoveolar retinal teleangiectasis. Retina. 2010; 30: 317-326.

10. Toto L, Di Antonio L, Mastropasqua R, Mattei PA, Carpineto $P$, Borrelli $\mathrm{E}$, et al.: Multimodal imaging of macular telangiectasia type 2: focus on vascular changes using optical coherence tomography angiography. Invest Ophthalmol Vis Sci. 2016; 57: 0СT268-0СT276.

11. Spaide RF, Klancnik JM Jr., Cooney MJ: Retinal vascular layers imaged by fluorescein angiography and optical coherence tomography angiography. JAMA Ophthalmol. 2015; 133: 45-50.

12. Nalci H, Sermet F, Demirel S, Ozmert E: Optic Coherence Angiography Findings in Type-2 Macular Telangiectasia. Turk J Ophthalmol. 2017; 47: 279-284.

13. Runkle AP, Kaiser PK, Srivastava SK, Schachat AP, Reese JL, Ehlers JP: OCT angiography and ellipsoid zone mapping of macular telangiectasia type 2 from the AVATAR study. Invest Ophthalmol Vis Sci. 2017; 58: 3683-3689.

14. Klein R, Blodi BA, Meuer SM, Myers CE, Chew EY, Klein BE: The prevalence of macular telangiectasia type 2 in the Beaver Dam eye study. Am J Ophthalmol. 2010 Jul; 150(1): 55-62.e2.

15. Aung KZ, Wickremasinghe SS, Makeyeva G, Robman L, Guymer RH: The prevalence estimates of macular telangiectasia type 2: the Melbourne Collaborative Cohort Study. Retina. 2010 Mar; 30(3): 473-478.

The paper was originally received 10.03.2019 (KO-00201-2019)/ Praca wpłynęła do Redakcji 10.03.2019 r. (KO-00201-2019) Accepted for publication 02.04.2019/

Zakwalifikowano do druku 02.04.2019 r.

Reprint requests to (Adres do korespondencji): Joanna Moneta-Wielgoś, MD, PhD ul. Szaserów 128 04-141 Warszawa e-mail: j.mw@vp.pl 